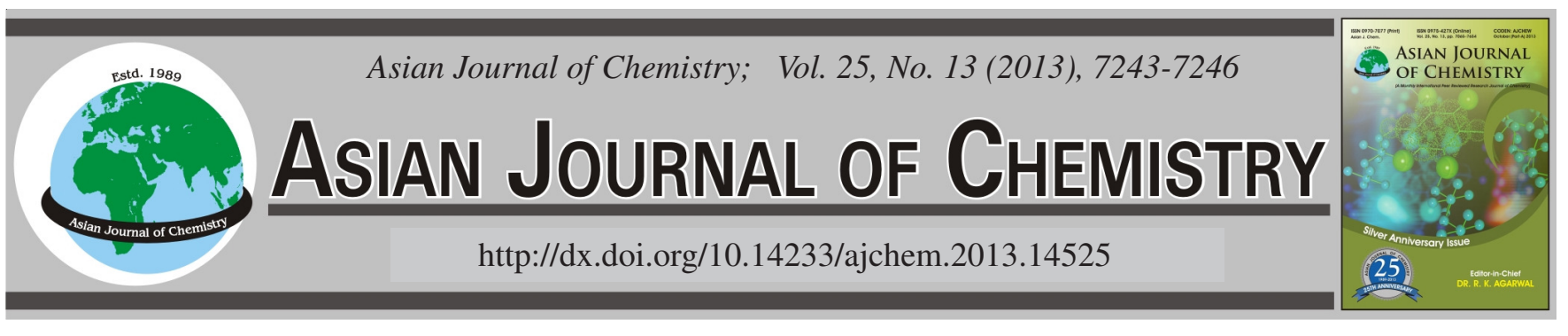

\title{
Biodegradation of Ammonium by Suspended and Immobilized Cells of Acinetobacter sp. Y1
}

\author{
YongKang $\mathrm{Lv}^{1, *}$, JiEYONG YANG ${ }^{1}$ and YUXIANG LiU ${ }^{2}$
}

${ }^{1}$ Key Laboratory of Coal Science and Technology, Ministry of Education and Shanxi Province, Taiyuan University of Technology, Taiyuan, Shanxi Province, P.R. China

${ }^{2}$ College of Environmental Science and Engineering, Taiyuan University of Technology, Taiyuan 030024, Shanxi Province, P.R. China

*Corresponding author: Tel: +86 13803466832; E-mail: yongkanglv@163.com

(Received: 5 September 2012;

Accepted: 19 June 2013)

AJC-13681

\begin{abstract}
A heterotrophic nitrifier Y1 was isolated from the activated sludge of a coking wastewater treatment. According to the result, the strain confirmed the final ammonium removal efficiency $c a .95 .66 \%$ in $120 \mathrm{~h}$, DNA sequencing and homologous analysis of $16 \mathrm{~s}$ rRNA gene identified that strain Y1 belonged to Acinetobacter sp. Poly(vinyl alcohol) was used as a gel matrix to immobilize Acinetobacter sp. Y1 by repeated freezing and thawing. The factors affecting ammonium removal of immobilized cells were studied and the results showed that the immobilized cells could tolerate a higher ammonium concentration than that of suspended cell. Storage stability and reusability tests revealed that the ammonium removal functions of immobilized cells were steady after respected use for 20 times or storing at $4{ }^{\circ} \mathrm{C}$ for $50 \mathrm{~d}$. All these experimental results showed that immobilized Acinetobacter sp. strain Y1 possessed a good application potential in the treatment of coking wastewater.
\end{abstract}

Key Words: Ammonium biodegradation, Immobilized cells, Suspended cells, Acinetobacter sp.Y1.

\section{INTRODUCTION}

Nowadays, ammonium-nitrogen is one of the most serious environmental pollutants, which mainly came from industrial processes, such as industrial, agricultural, urban and domestic wastewater. Components in coking wastewater are complex, in which contain high concentration of ammonium and a number of toxic and difficult decompounded organic compounds ${ }^{1,2}$. If the wastewater doesn't treated adequately, it will also bad for people's health. Consequently, how to remove ammonium from coking wastewater efficiently and economically has becoming a hot research field these years ${ }^{3}$.

There are many methods to remove ammonium and compared with physico-chemical methods, the biodegradation method of ammonium removal is universally preferred because of lower costs ${ }^{4-6}$. In this sense, biological treatment of ammonium contamination has therefore obtained an increasing attention in pollution prevention and many ammonium-removing bacteria have been isolated ${ }^{7-9}$. However, the use of suspended cells for wastewater treatment in activated sludge processes creates problems such as solid waste disposal ${ }^{10-12}$. Immobilized cells have been showed to be effective to treat ammonium-containing wastewater. So more and more people begin to take the way into consideration.

The aim of this study is to remove ammonium by using suspended cells and immobilized cells of Acinetobacter $s p$. Y1.Facters of affecting ammonium biodegradation process and stability of immobilized cells were also investigated.

EXPERIMENTAL

Samples of activated sludge were obtained from Shanxi Coal Gasification Company Wastewater Treatment Facility, Taiyuan China. Poly(vinyl alcohol) with an average degree of polymerization of 2400-2500 were purchased from Tianjin Chemical Factory. All other chemicals used were of the highest purity available. Heterotrophic ammoniation (HA) medium was used for the enrichment and isolation of ammoniumremoving strains. The strains were grown aerobically at $30^{\circ} \mathrm{C}$ in heterotrophic ammoniation media at $\mathrm{pH}$ 7.4-7.8 containing (per liter) $2.829 \mathrm{~g}\left(\mathrm{NH}_{4}\right)_{2} \mathrm{SO}_{4}, 30.105 \mathrm{~g} \mathrm{C}_{6} \mathrm{H}_{5} \mathrm{O}_{7} \mathrm{Na}_{3} \cdot 2 \mathrm{H}_{2} \mathrm{O}, 0.2$ $\mathrm{g} \mathrm{K}_{2} \mathrm{HPO}_{4}, 0.12 \mathrm{~g} \mathrm{NaCl}, 0.05 \mathrm{~g} \mathrm{MgSO}_{4} \cdot 7 \mathrm{H}_{2} \mathrm{O}, 0.01 \mathrm{~g}$ $\mathrm{MnSO}_{4} \cdot 4 \mathrm{H}_{2} \mathrm{O}, 0.01 \mathrm{~g} \mathrm{FeSO}$ and $1000 \mathrm{~mL} \mathrm{H} \mathrm{H}_{2} \mathrm{O}$. $\left(\mathrm{NH}_{4}\right)_{2} \mathrm{SO}_{4}$ of different concentration was added to the sterile heterotrophic ammoniation media as the sole nitrogen source and $\mathrm{C}_{6} \mathrm{H}_{5} \mathrm{O}_{7} \mathrm{Na}_{3} \cdot 2 \mathrm{H}_{2} \mathrm{O}$ as the sole carbon source in synthetic heterotrophic ammoniation medium.

Analysis methods: The quantities of ammonium in liquid medium removed by bacteria were estimated by photometric determination with Nessler's reagent measuring the absorbance of the culture solution at $420 \mathrm{~nm}$.

Selection and isolation of the ammonium-removing strains: For selection of the desired microbial consortia, beef 
extract peptone medium was used for enrichment culture and heterotrophic ammoniation medium was used for screening heterotrophic ammoniation bacteria. The heterotrophic ammoniation medium was autoclaved for $0.5 \mathrm{~h}$ at $121^{\circ} \mathrm{C}^{13,14}$. Sterile media $(100 \mathrm{~mL})$ in $250 \mathrm{~mL}$ conical flask $(\mathrm{n}>10)$ were inoculated with $1 \mathrm{~mL}$ of fresh activity sludge and incubated at $30{ }^{\circ} \mathrm{C}$ on a rotary shaker at $120 \mathrm{rpm}$. Everyday $5 \mathrm{~mL}$ medium was taken out in sterilized for detecting ammonium's surplus ,which was determined by photometric determination with Nessler's reagent. When the test proved positive, $1 \mathrm{~mL}$ of the enrichment cultures was transferred to fresh medium. Purified isolates were obtained by repeated streaking on fresh washedagar plates. According to the foregoing steps, we obtained several strains. And each isolate was then tested for its ability to remove ammonium in the end.

Immobilization of bacteria: Poly(vinyl alcohol) was heated to dissolve in distilled water at $10 \%$ by heating the gel at $100{ }^{\circ} \mathrm{C}$, then sodium alginate was added to dissolve in the poly(vinyl alcohol) solution and kept overnight at room temperature ${ }^{15-17}$. The bacterial cells were collected by centrifugation at $8000 \mathrm{r} / \mathrm{min}$ for $10 \mathrm{~min}$, the concentrated bacteria was mixed with the dissolved poly(vinyl alcohol) and stirred to be uniform. The mixed solution was then dropped into a mixed solution of $100 \mathrm{~mL}$ boric acid and calcium chloride using a syringe to form beads and stirred for separate these beads and which were stored at $-4^{\circ} \mathrm{C}$ for $24 \mathrm{~h}$. After $24 \mathrm{~h}$, the beads were thawed at $4{ }^{\circ} \mathrm{C}$. The freezing and thawing process was repeated for two additional cycles to increase the mechanical strength of immobilized cells ${ }^{18-21}$. Finally, the beads were swashed in sterile water and the swashed beads were kept at $4{ }^{\circ} \mathrm{C}$ for further use.

Storage stability and reusability of immobilized cells: In order to study the storage stability of the free cells and immobilized cells, both of them were stored for $0,10,20,30$, 40 and $50 \mathrm{~d}$ at $4{ }^{\circ} \mathrm{C}$, respectively. In order to examining the storage stability of the cell, we detected the ammonium removal rates. They were grown at $30^{\circ} \mathrm{C}$ for $4 \mathrm{~d}$ with shaking at $120 \mathrm{rpm}$ in heterotrophic ammoniation media $(\mathrm{pH} 7.7)$ consisting of $600 \mathrm{mg} / \mathrm{L}$ ammonium. In order to test the reusability of immobilized cells, the immobilized cells were repeated used in several consecutive ammonium removal processes and the ammonium removal rate was examined. The immobilized cells were incubated in heterotrophic ammoniation media for 4 day as one cycle. The immobilized cells were used again separately for removing together with fresh medium and which contained the required amount of ammonium under the same experimental conditions.

Identification of strain Y1 by 16s rDNA sequence: $16 \mathrm{~s}$ rDNA fragment was amplified with the primers $27 \mathrm{~F}$ (5'AGAGTTTG .ATCMTGGC-TCAG-3') and 1492R (5'CGGYTACCTTg3TTACGACTT-3'). PCR reaction was done as originally described by Cai et $a .^{22}$. The PCR product was cloned into the pMD 18-T vector (TaKaRa Biotechnology Co.) following the manufacturer's instruction. 16s rDNA was sequenced by Shanghai Sangon Biological Engineering Technology and Services Co., Ltd. The final sequence of 1500 bp was submitted to the Gen-Bank under accession number EU016146.1. The sequence was submitted to a BLAST search of the NCBI GenBank database to identify the organism.

\section{RESULTS AND DISCUSSION}

Biodegradation test of ammonium by suspended and immobilized cells: Poly(vinyl alcohol) as a gel matrix was utilized to immobilize Acinetobacter $s p$. strainY1 by repeated freezing and thawing. Factors affecting ammonium removal of immobilized cells such as ammonium concentration, $\mathrm{pH}$, $\mathrm{C} / \mathrm{N}$, temperature and shaking speed were investigated ${ }^{23}$. In order to identify the effect of ammonium concentration on the ammonium removal, suspended and immobilized cells were grown in liquid heterotrophic ammoniation medium $(\mathrm{pH}=$ 7.7) at $30^{\circ} \mathrm{C}$ with various initial ammonium concentration. Comparing with suspended cells, immobilized cells displayed a lower removal rate when ammonium concentrations were below $300 \mathrm{mg} / \mathrm{L}$. However, when ammonium concentrations were over $300 \mathrm{mg} / \mathrm{L}$, immobilized cells showed better ammoniumremoving efficiencies (Fig. 2). Comparison of ammonium concentration on suspended and immobilized cells culture.

By enrichment culture, we selected the Y1 strain, due to its high ammonium-removing rate. Consequently, it was tested for its capacity to make use of ammonium at concentrations from $100-1000 \mathrm{mg} / \mathrm{L}$ in liquid heterotrophic ammoniation medium. As shown in the Fig. 1, we could see that Y1 were able to removing around $95.66 \%$ ammonium within $120 \mathrm{~h}$ with an initial concentration of $600 \mathrm{mg} / \mathrm{L}$ ammonium.

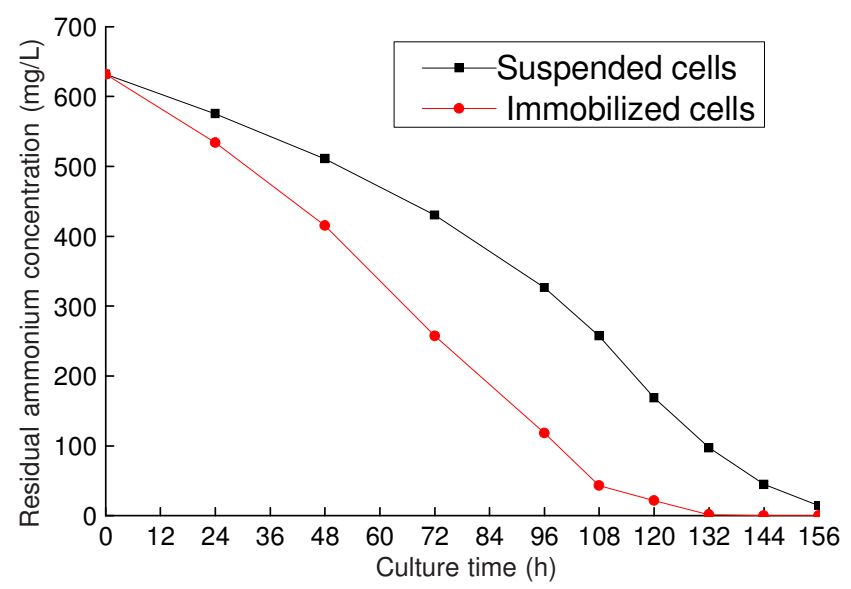

Fig. 1. Ammonium-removing curves of strain Y1. The ammonium removal of suspended and immobilized cells

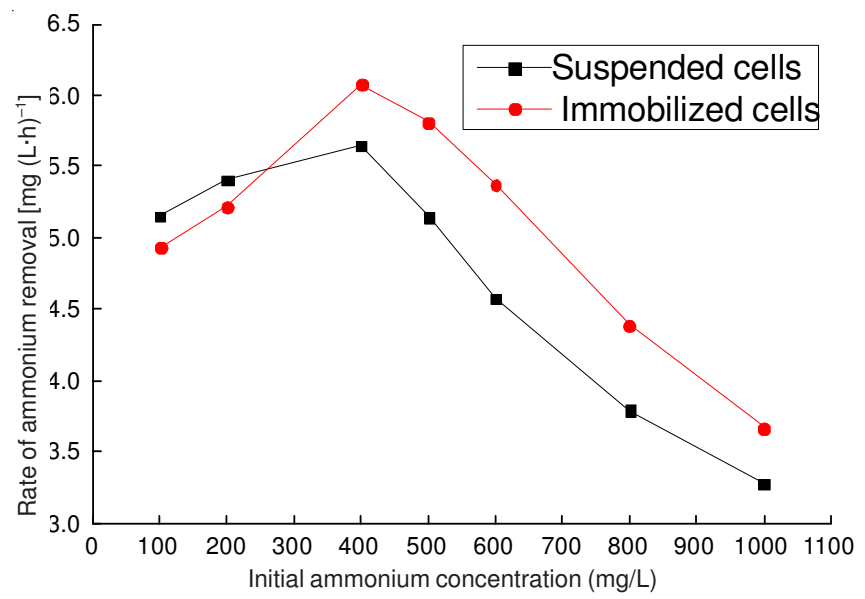

Fig. 2. Effect of initial ammonium concentration on grown at $30^{\circ} \mathrm{C}$ for $5 \mathrm{~d}$ with shaking speed at $120 \mathrm{rpm}$ 
Comparison of initial $\mathrm{pH}$ on removal rate of ammonium by suspended and immobilized cells culture: Fig. 3 demonstrates the ammonium removal rate by suspended and immobilized cells at a variety of $\mathrm{pH}$ values. These experiments were operated at $30{ }^{\circ} \mathrm{C}$ with ammonium concentration of $600 \mathrm{mg} / \mathrm{L}$. Fig. 3 suggested that the immobilized cells have higher removal rates and wider $\mathrm{pH}$ range than that of suspended cells. The ammonium removal rate by suspended and immobilized cells were not changed rapidly when $\mathrm{pH}$ was in the range of 7.79.1. When $\mathrm{pH}$ was dropped below 7.7, the removal rates of the suspended and immobilized cells were both decreasing. Especially, when $\mathrm{pH}$ was at 5.0 and 11.0, ammonium-removing activity of suspended cells was completely restrained. However, immobilized bacteria still preserved an acceptable removal rate of 2.97 and $2.89 \mathrm{mg}^{\prime \prime}(1 \mathrm{~h})^{-1}$ at the same $\mathrm{pH}$. In a word, immobilized cells' tolerance ability to acid conditions was much better than that of suspended cells.

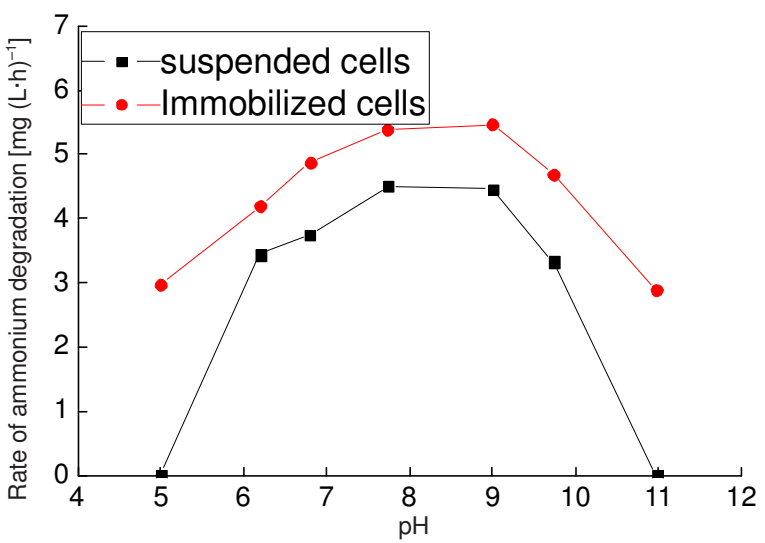

Fig. 3. Effect of $\mathrm{pH}$ on ammonium removal of suspended and immobilized cells

Comparison of temperature on removal rate of ammonium by suspended and immobilized cells culture: In order to confirm that immobilized cells can stand a much wider temperature changes than suspended cells, we carried out the experiments at a temperature range from $20-45^{\circ} \mathrm{C}$ at $\mathrm{pH}=7.7$ with ammonium concentration of $600 \mathrm{mg} / \mathrm{L}$. The result of the experiments on removal rate of ammonium were shown in Fig. 4. From the Fig. 4, we could see that both of two conditions were the same in the optimum temperature $\left(30^{\circ} \mathrm{C}\right)$, the removal rates were 4.577 and $5.379 \mathrm{mg}(1 \mathrm{~h})^{-1}$ for suspended and immobilized cells, respectively. In the range of $20-45^{\circ} \mathrm{C}$, the immobilized cells demonstrated a higher value of removal rate than that of suspended cells. Above all, when the temperature exceeded $35^{\circ} \mathrm{C}$, with the increase of the temperature, the suspended cells' curve dropped rapidly, but immobilized cells' curve decreased slowly. It is also noted that when the suspended cells have a low removal rate at $45^{\circ} \mathrm{C}$ (removal rate of $\left.1.325 \mathrm{mg}(1 \mathrm{~h})^{-1}\right)$, the immobilized cells still preserved a removal rate of $2.924 \mathrm{mg}(1 \mathrm{~h})^{-1}$. All these results verified that the endurance of immobilized cells to temperature was much better than that of suspended cells. So we reached a result that the immobilization increased the thermal stability of the cells under the protection of poly(vinyl alcohol) carrier.

Comparison of shaking speed on removal rate of ammonium by suspended and immobilized cells culture

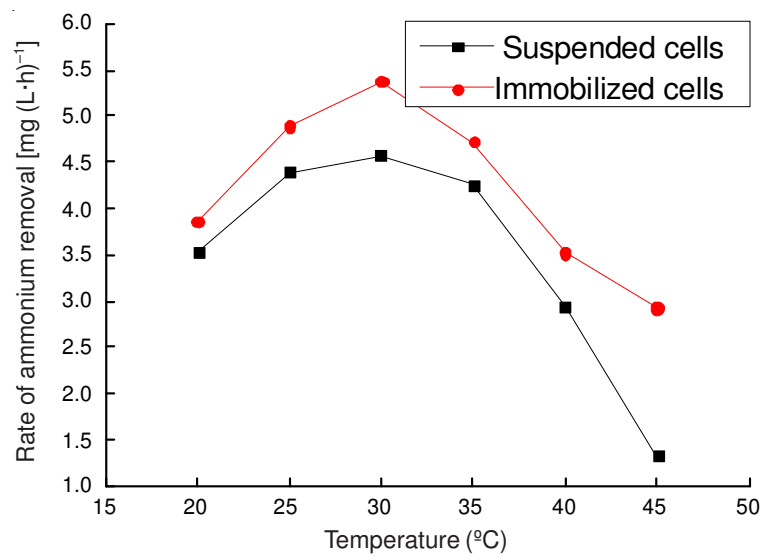

Fig. 4. Effect of temperature on ammonium removal of suspended and immobilized cells

(Fig. 5): According to the theory, there may be simultaneous nitrification and denitrification when the shaking speed was low, which were conducive to ammonium removal. However, both nitrifying bacteria and nitrite bacteria were aerobic bacteria, so low shaking speed was not conducive to the occurrence of nitrification. When the shaking speed was 120 $\mathrm{rpm}$, ammonium removal rates reached stabilized. With the continuous increase of the shaking speed, the removal rates were nearly fixed and that they were a little declining. All those indicated that adaptation to shaking speed of immobilized cells was better than suspended cells.

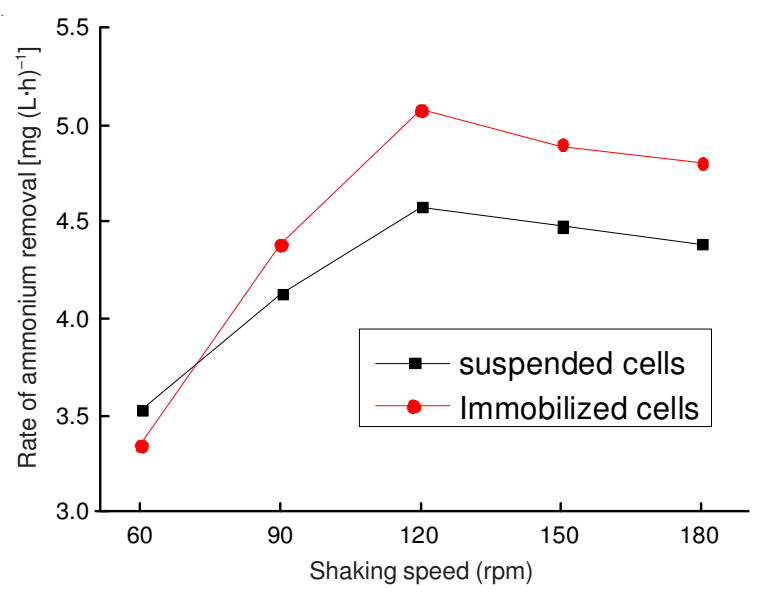

Fig. 5. Effect of shaking speed on ammonium removal of suspended and immobilized cells

Comparison of $\mathrm{C} / \mathrm{N}$ ratios on removal rates of ammonium by suspended and immobilized cells culture: The effect of $\mathrm{C} / \mathrm{N}$ ratios on the two conditions using a initial concentration of $600 \mathrm{mg} / \mathrm{L}$ was examined in shaking culture (Fig. 6). We selected a range $\mathrm{C} / \mathrm{N}$ ratios from 6 to 22 at $\mathrm{pH}=7.7$. On the basis of the experimental results, we could conclude that immobilized cells had a much better removal rates than suspended cells. When the $\mathrm{C} / \mathrm{N}$ ratios were among 6-14, the ammonium removal rate became much better with the increase of $\mathrm{C} / \mathrm{N}$ ratios. When the $\mathrm{C} / \mathrm{N}$ ratio was 14 , the two conditions reached optimal removal rates and were 4.577 and $5.473 \mathrm{mg}$ $(1 \mathrm{~h})^{-1}$ for suspended and immobilized cells. When $\mathrm{C} / \mathrm{N}$ ratios exceeded 14, both suspended cells and immobilized cells were almost constant. It meant that excess carbon source had little 
impact on the removal rates in the media. The most balanced $\mathrm{C} / \mathrm{N}$ ratio was 14 .

Storage stability and reusability of immobilized cells of Acinetobacter sp. Y1: After long-term storage and operation of the immobilized cells, it was important to investigate the stability of immobilized cells system in practical application (Fig. 7). With the increase of storage time, immobilized cells maintained a steady ammonium removal rates. Most of all, immobilized cells still had a removal rate of $90.47 \%$ after being storing for $50 \mathrm{~d}$ at $4{ }^{\circ} \mathrm{C}$. However, the removal rates of suspended cells declined sharply after storing for $10 \mathrm{~d}$ at $4^{\circ} \mathrm{C}$ and almost lost all of its activity after storing for $50 \mathrm{~d}$ at $4{ }^{\circ} \mathrm{C}$. From the above, we could obtain that immobilized cells had more powerful storage stability than that of suspended cells.

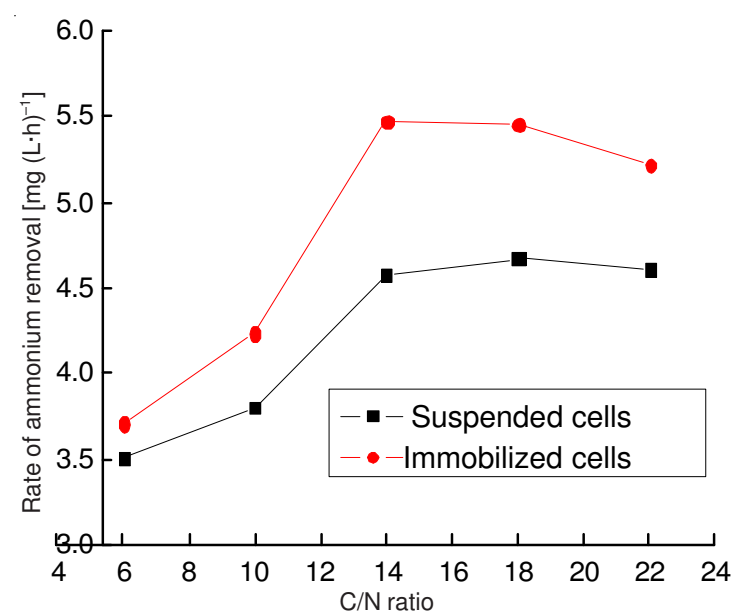

Fig. 6. Effect of $\mathrm{C} / \mathrm{N}$ ratios on ammonium removal of suspended and immobilized cells

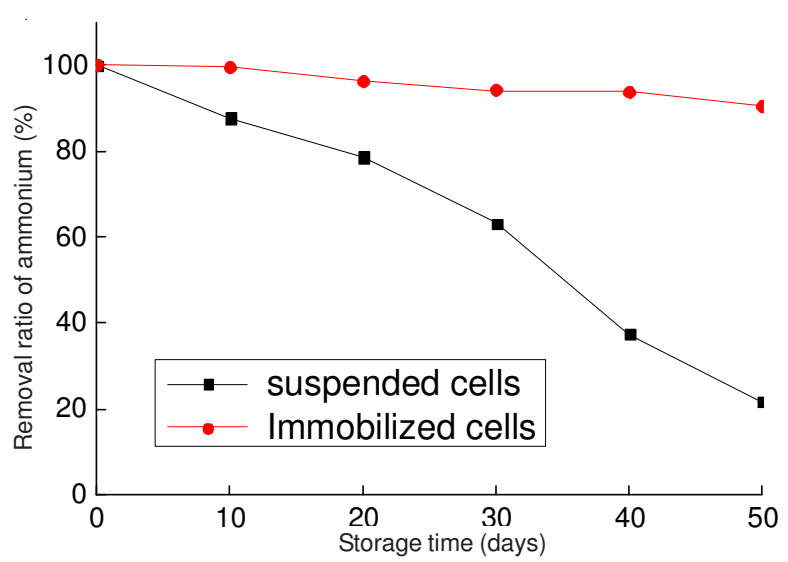

Fig. 7. Comparison of storage stability at $4{ }^{\circ} \mathrm{C}$ between suspended and immobilized cells

In addition, poly(vinyl alcohol) immobilized cells were tested in several continuous ammonium removal processes to identify if there was deactivation of cells after being reused. The results showed that the ammonium-removing ability only decreased $10.3 \%$ after the immobilized strain Y1 was used for 20 cycles. It meant that immobilized cells could be repeated use for at least 20 cycles. We also found that the poly(vinyl alcohol) cells retained a high mechanical strength. These results were significantly better than previous report of immobilized fkdstonia metallidurans $\mathrm{CH} 34$ entrapped in sodium alginate ${ }^{24}$.

\section{Conclusion}

The study investigated the removing rate of ammonium by suspended cells and immobilized Acinetobacter sp. strain Y1. We obtained the following conclusion: (1) The new selected ammonium-removing bacterium was isolated from the coking wastewater, but it was of high biodegradation activity and high tolerance of ammonium. The strain was capable of removing $600 \mathrm{mg} / \mathrm{L}$ in liquid heterotrophic ammoniation medium by $95.66 \%$ in $120 \mathrm{~h}$. According to the $16 \mathrm{~s}$ RNA gene sequence analysis, it is concluded that the strain belonged to the genus Acinetobacter and is hereby named Acinetobacter sp. Y ${ }^{25}$. (2) Poly(vinyl alcohol) was used as a gel matrix to immobilize the strain Y1. The immobilized cells have higher removal rate and wider $\mathrm{pH}$ range than that of suspended cells. Temperature has a less effect on immobilized cells than that of suspended cells. (3) The immobilized cells have much better storage stability and can be repeated use for at least 15 cycles.

\section{ACKNOWLEDGEMENTS}

This study was supported by the National Natural Scientific Foundation of China (No. 51078252), International Cooperation Projects of Shanxi Province (2010081018) and Nature Science Foundation of Shanxi Province (2010011016-1).

\section{REFERENCES}

1. S.J. You and W.Y. Chen, Int. Biodeterior. Biodegrad., 62, 244 (2008).

2. X.P. Yang, S.M. Wang, D.W. Zhang and L.X. Zhou, Bioresour. Technol., 102, 854 (2011).

3. H.S. Joo, M. Hirai and M. Shoda, J. Biosci. Bioeng., 100, 184 (2005).

4. S.M. Taylor, Y.L. He, B. Zhao and J. Huang, J. Environ. Sci., 21, 1336 (2009).

5. P.G. Octavio, F.M.E. Escalante, L.E. de-Bashan and Y. Bashan, Water Res., 45, 11 (2011).

6. H.S. Joo, M. Hirai and M. Shoda, J. Biosci. Bioeng., 103, 66 (2007).

7. Y.M. Chao, I.C. Tseng and J.S. Chang, J. Hazard. Mater., B137, 1781 (2006).

8. M. Gholamreza and H. Mahdi, Sep. Purif. Technol., 77, 187 (2011).

9. G.M. Cao, Q.X. Zhao, X.B. Sun and T. Zhang, Enzyme Microb. Technol., 30, 49 (2002).

10. X.L. Qiao, Z.J. Zhang, Q.X. Chen and Y.J. Chen, Desalination, 222, 340 (2008).

11. S. Chintala, M. Mallavarapu, V. Kadiyala and N. Ravi, Int. Biodeterior. Biodegrad., 68, 24 (2012).

12. N.J. Manju, V. Deepesh, C. Achuthan, P. Rosamma and I.S. Bright Singh, Aquaculture, 294, 65 (2009).

13. N. Takayuki, Y. Taro, M. Hirotsugu, I. Zensuke and I. Hisao, J. Ferment. Bioeng., 86, 351 (1998).

14. F. Raposo, R. Borja, E. Sanchez and M.A. Martin, Process Biochem., 39, 425 (2003).

15. Y.J. Liu, A.N. Zhang and X.C. Wang, J. Biochem. Eng., 44, 187 (2009).

16. L. Wu, G. Ge and J.B. Wan, J. Environ. Sci., 21, 237 (2009).

17. Y. Wang, Y. Tian, B. Han, H.B. Zhao, J.N. Bi and B.L. Cai, J. Environ. Sci., 19, 222 (2007).

18. M.V. Jiménez-Pérez, P. Sánchez-Castillo, O. Romera, D. FernándezMoreno, C. Pérez-Mart inez, Enzym. Microb. Technol., 34, 392 (2004).

19. M. Gomez, G. Matafonova, J.L. Gomez, V. Batoev and N. Christofi, J. Hazard. Mater., 169, 46 (2009).

20. F.S. Omer, S. Rabia and T. Turgay, Int. Biodeterior. Biodegrad., 71, 67 (2012).

21. K.C. Chen, J.Y. Wu, C.C. Huang and Y.M. Liang, J. Biochem., 101, 241 (2003).

22. B. Cai, Y. Han and B. Liu, Lett. Appl. Microbiol., 36, 272 (2003).

23. Y. Lu, L.H. Yan, Y. Wang, S.F. Zhou, J.J. Fu and J.F. Zhang, J. Hazard. Mater., 165, 1091 (2009).

24. Z.-G. Wu, Y.-M. Wang, Z.-H. Xing and X.-W. Wu, Microbiology (China), 32, 31 (2005) (In Chinese).

25. P.H. James, J. Phycol., 34, 757 (1998). 